\title{
KALEVALAMITTAISEN RUNONLAULUN RYTMILAIT
}

Vanhemman kansanlaulun rytmiä on käsiteltävä monitasoisena järjestelmänä, muttei säännönmukaisen tai vaihtelevan metrin perusteella. Musiikillisen rytmin perustana on yhtä (periodisesti toistuvaa) rakenneyksikköä vastaava rytmikuvio, joka koostuu pitkistä ja lyhyistä (tai samanpituisista) kestoista. Tämä on taso, jossa sävelrytmi yhdistyy säerakenteeseen; konkreettinen rytmi ja konkreettinen säe saattavat poiketa siitä suuremmassa tai vähemmässä määrin. Lyhyt ja pitkä kesto ovat kaksi erilaista kestokategoriaa ilman tarkkoja kestosuhteita. Tällainen rytmikuvio tai rytmikaava on alisteinen koristelulle, tietyille musiikillisille mutaatioille sekä konkreettisten säkeiden prosodisista erikoispiirteistä johtuville muutoksille.

Lineaarisen musiikin rytmisen jäsentelyn yksi varhaisimpia systematisointiyrityksiä on keskiaikainen modaalirytmiikka. Se, että kalevalamittaisen runonlaulun kuvaamisessa on näistä käsityksistä apua, voisi olla osoituksena runonlaulun kuulumisesta analogiseen kulttuurikerrostumaan (varhaisen keskiajan eurooppalaiseen laulukulttuuriin) eikä geneettisistä yhteyksistä.

Tarkastelemme seuraavassa eestiläisissä, vatjalaisissa, karjalaisissa ja inkeroisten runonlaulussa laajalti käytettyjä rytmikaavoja. Muutaman laulun kohdalla tarkastelemme lähemmin, miten rytmiä olisi mahdollista kuvata. 


\section{Teoreettinen tausta}

Itämerensuomalaisten runonlaulu, jota eestiläiset nimittävät regilauluksi ja suomalaiset kalevalaiseksi lauluksi, on laaja ja yhtenäinen lauluperinne, jota eivät tunne ainoastaan itäisin kansa - vepsäläiset - eikä eteläisin kansa - liiviläiset. Liiviläisistä tätä ei saisi kuitenkaan väittää täydellä varmuudella. Henkilökohtaisesti olen valmis uskomaan $H$. Tamperen olettamuksia (Tampere 1977), että joskus menneisyydessä on saattanut olla olemassa myös liivinkielinen vastaavanlainen lauluperinne, mutta se on hävinnyt yhdessä liiviläisen asutuksen kanssa Pohjois-Latviassa.

Oman kiinnostukseni kohteena ovat tämän perinteen musiikilliset yhteispiirteet. Tässä artikkelissa keskityn rytmi-ilmiöihin. Aihe on todella kiinnostava, koska kalevalamittaisten runonlaulujen sävelmät vaikuttavat pääpiirteissään hyvin samanlaisilta. Ihan samanlaisia sävelmiä löytyy kuitenkin tavattoman vähän jopa lähellä toisiaan sijaitsevien paikkakuntien ohjelmistossa. Tämä on itse asiassa hämmästyttävää, kun ottaa huomioon rajoitetụt rakennemahdollisuudet.

\section{Kaksi rytmisen ajattelun periaatetta}

Runonlaulun rytmiikkaa ei ole tarkoituksenmukaista kuvailla länsieurooppalaisessa musiikissa 1500-1600-luvulla syntyneiden metri-, tahtilaji- ym. teorioiden avulla, vaikka useimmat sävelet ovat varsin säännönmukaisia, niin että niitä myös voidaan merkitä $(5 / 4,4 / 8,5+3 / 8$ jne.). Runonlaulu on peräisin varhaisemmalta ajalta. Kuten monissa lineaarisissa musiikkikulttuureissa, myös runonlaulussa rytminen ajattelu rakentuu säettä tai säepuoliskoa vastaavien rytmikuvioiden avulla. Tämä on kansanmusiikintutkijoille täysin tunnettu rytmisen ajattelun periaate, vaikkakin Euroopan kansojen kansanmusiikintutkijat ovat pyrkineet merkitsemään erilaisia rytmirakenteita enimmäkseen tahtilajien avulla. Suuri, kenties jopa valtaosa Euroopan kansojen musiikkiperinteestä onkin peräisin myöhemmältä ajalta ja perustuu useista rytmiikan erityispiirteistä huolimatta lähinnä metriseen ajatteluun. Näiden kahden ajattelutavan ero on karkeasti hahmoteltuna seuraava: a) rytmikuviolla on omat rakenne-elementit (lyhyet ja pitkät, painolliset ja painottomat yksiköt) sekä tietty jakso (periodi), jonka jälkeen kuvio toistuu; b) metrinen ajattelu perustuu abstrakteille iskuille sekä näistä iskuista muodostuville iskualoille, jotka täytetään vapaasti jatkuvasti muuttuvilla rytmikuvioilla. 
Curt Sachs pitää oikeana nimittää metriseksi juuri ensimmäistä, rytmikuvioihin perustuvaa ajattelutapaa - analogiat löytyvät runoudesta, jossa runomitta esittää pitkien ja lyhyiden painojen kaavan (ranskal. vers mesurés e. vers mètriques) (Sachs 1953). Kuitenkin musiikkitieteessä tämä termi on tullut käyttöön nimenomaan toisessa merkityksessä. Metri sellaisenaan kuin se oli eurooppalaisessa moniäänisessä musiikissa 1700-lukuun tultaessa vakiintunut (1700- ja 1800-luvuilta juontavat juurensa useimmat nykyisin käytettävät musiikkitermit ja ajattelutavat) on kuitenkin varsin monimutkainen ja erityisesti harmonisen, ei-lineaarisen musiikin järjestelmä. Sen johtaminen takaisin klassisen runouden vanhoihin runomittoihin olisi asian pelkistämistä. Samassa teoksessa Sachs käyttää rytmikuvioihin perustuvasta ajattelusta termiä additiivinen, lisääntyvä rytmi - kyseessä ei ole siis joku määrätty kesto, joka jaettaisiin tasavertaisiin osiin, vaan toistuvan, säännönmukaista järjestelmää luovan kuvion muodostavat ryhmät, esimerkiksi $2+1,3+3+2$ tai mikä tahansa pitkien ja lyhyiden kestojen yhdistelmä. Vastakohtana olisi divisiivinen rytmi. Sachs (s.25) kiinnittää huomion myös siihen, että additiivinen rytmi on konkreettinen, mutta metri eli jakautuva rytmi ideaalinen. Haluaisin kiinnittää huomion siihen, että myös additiivista rytmiä kuvataan kuitenkin sen avulla. Mittana tai iskuna on lyhyt kesto ja pitkä on lyhyttä kaksi, kolme (neljä, viisi) kertaa pitempi.

\section{Pitkät ja lyhyet kestot}

Koko tämän tutkielman kulmakivenä on ajatus, että tietyllä aikakaudella oli (tai kenties on vieläkin) lineaarisen musiikin rytmikuvioissa oleellista vain pitkien ja lyhyiden kestojen vastakkaisuus. Käytännössä sekä lyhyiden että pitkien kestojen joukossa voi olla paljon erilaisia kestoja. Tärkeintä on, että ne selvästi erottuisivat toisistaan kahtena ryhmänä. Rytmikuvion elementteinä ovat pitkät ja lyhyet tai myös samanpituiset kestot. Jos välttämättä halutaan, voidaan tietysti mitä tahansa rytmiä merkitä vaihtuvien tahtilajien avulla. Haluaisin vielä kerran korostaa jo mainitsemaani ajattelutapojen erilaisuutta. Tämä ei välttämättä sen kummemmin vaikuta käytäntöön, sillä kaikki nuottikirjoitus on sopimuksenvaraista, mutta se heijastaa kirjoittajan käsityksiä musiikista. Tahtia ja tahtilajia määriteltäessä emme käsitä pitkää kestoa laadullisesti erilaisena elementtinä, vaan kahden tai kolmen (joskus useammankin) lyhyen elementin summana. Samalla edellytämme suhteellisen pysyviä kestosuhteita ja kuitenkin myös metriä. 
Totta on, ettei pitkä elementti eroakaan lyhyestä kvalitatiivisesti vaan kvantitatiivisesti, mutta kvantitatiivisesti eri ryhmiin kuuluvat yksiköt käyttäytyvät rytmikuvioissa itsenäisesti. Rytmistä kaavaa voidaan koristella, mutta nämä lyhyet eivät ole pysyvyydeltään, säkeeseen mukautuvaisuudeltaan eivätkä aina myös intonaatioltaan tasavertaisia rytmikuvioissa itsenäisenä yksikkönä esiintyvän lyhyen elementin kanssa. Tahtilajeihin perustuvasta nuottikirjoituksesta lukijalle syntyy kuitenkin kuva abstraktisesta iskurivistä, jossa voidaan vapaasti muodostaa rytmejä. Tämän teorian mukaan lyhyiden kestojen käsittely muuttuu jopa enemmän kuin pitkien. Jos lähdetään edellytyksestä, että kestosuhteet voisivat olla tai että niiden tulisi olla tarkkoja, tai että olisi suotavaa merkitä ne mahdollisimman tarkasti nuottikirjoitukseen, niin juuri lyhyiden kestojen kohdalla joudutaan turvautumaan pisteellisiin nuotteihin, trioleihin, viivoihin, kaariin yms. nuottikirjoituksen täsmennyksiin (koska kestoerot ovat huomattavampia). Jokainen herkkäkorvainen nuottikirjoituksen tekijä joutuu kuitenkin tyytymättömänä toteamaan, ettei ihanteellinen täsmällisyys ole tavoitettavissa.

Kalevalamittaisen runonlaulun kestoja on tutkittu akustisin mittauksin varsin vähän, käytettävissä oleviin mittaustuloksiin olisi kuitenkin syytä viitata. Jo kauan sitten olen mitannut tavuvokaalien pituuksia kahdessa syllabiseen rytmiin perustuvassa laulussa (Lippus 1977) ja osoittanut, että samanpituisista musiikillisista kestoista huolimatta vokaalien kestot eroavat kaksi tai kolme tai joskus jopa kuusi kertaa riippuen sanojen prosodisesta rakenteesta. Tavuvokaali ei tietenkään täytä tavun koko kestoa, mutta mitatuissa klusiilienvälisissä rakenteissa se oli itse asiassa ainoa todellinen melodian välittäjä. Näiden erojen merkitseminen nuottikirjoitukseen erilaisten merkkien avulla olisi tyhjänpäiväistä ja lukijan kannalta pikemminkin harhauttavaa eikä helpottavaa toimintaa. Lukija kokisi merkityt rytmit musiikillisina rytmeinä.

J. Ross teki v. 1988 yhteenvedon eräässä keinulaulussa esiintyvien sävelten kestoista. Keinulaulun perusrytmi on lyhyt-pitkä kesto jokaisella kaksitavuisella runojalalla. Mitatussa esityksessä korva erotti vielä suunnilleen puolet lyhyempiä korusäveliä. Tulokset osoittivat kahta toisistaan selvästi erottuvaa lyhyiden ja pitkien kestojen ryhmää. Ryhmän sisällä kestot erosivat toisistaan jo melkoisesti. Puolet lyhyempiä korunuotteja ei ollut mahdollista erottaa lyhyistä kestoista. 


\section{Nuottikirjoitus}

Edellä sanotun taustalla olisi syytä hieman tarkastella nuottikirjoitusta, sen tehtäviä sekä eurooppalaisen nuottikirjoituksen kehitystä. Jokainen nuottikirjoitus on sovinnainen järjestelmä musiikin oleellisten rakenteiden muistiinmerkitsemiseksi. Nuottikirjoitus sivuuttaa yksityiskohdat, jotka perinteen tunteva lukija tietää ennestään, samoin ne yksityiskohdat, jotka saattavat vapaasti muuttua ilman että esittävän kohdan identtisyys häviäisi. Epäoleellisten yksityiskohtien välittäminen on kirjoittajan kannalta tyhjänpäiväistä ja lukijan kannalta ärsyttävää. Tämä tarkoittaa sitä, että jokaiseen musiikkityyliin liittyvät tietyt nuottikirjoituksen sovinnaisuudet. Eurooppalainen nuottikirjoitus on jatkuvasti muuttunut. Jos ilmenee tarvetta jonkin uuden seikan muistiinmerkitsemiseksi, siihen kyllä löydetään keinot. Merkityksensä menettäneet ajatusmallit unohtuvat yhdessä niitä vastaavien nuottikirjoituksen keinojen kanssa.

On absurdia valittaa, ettei nuottikirjoituksessamme ole mahdollista välittää luonnonkansojen musiikkia. Nämä keinot eivät voi itsestään yllättäen syntyä nuottikirjoitukseen. Jokainen tutkija pystyy löytämään keinot kuvailtavan musiikin oleellisten mekanismien, tärkeiden rakenneosien ja niiden välisten suhteiden muistiinmerkitsemiseksi. Lähes tuhatvuotinen eurooppalainen nuottikirjoitus tarjoaa siihen paljon aineistoa, ja tarpeen mukaan voidaan merkkejä ja järjestelmiä kehittää myös itse. Nuottikirjoitusta tehtäessä on tehtävä itselleen selväksi, ettei nuottikirjoitus voi olla äänite. Samalla tavalla kuin kirjoitettu a-kirjain ei merkitse kaikille ihmisille samanlaista äännettä, myös nuottikirjoituksen kohdalla olisi oltava kokemusta siitä, miltä musiikki kuulostaa. Jos haluaa ymmärtää vierasta musiikkikulttuuria, tarvitaan ensin kokemusta sen soinnista - nuottikirjoitus on siihen liittyvä apuväline. Keskiaikaista musiikkia esitettäessä on itsestään selvää, että kaikki tietomme siitä on välillisten tietojen perusteella (nuottikirjoitus, teoriaopetus, säveltäjien laulajille ja soittajille antamat ohjeet, aikalaisten kuvaukset musiikista, kuvat jne.) tehty restauraatio. Emme tietäisi siitä yhtään enempää, vaikka silloin olisi pystytty "parempaan" nuottikirjoitukseen.

Äskeisellä haluan asettaa kyseenalaiseksi liian "tarkan" nuottikirjoituksen. Nuottikirjoitukselle ei saa asettaa tehtäviä, joita se ei pysty täyttämään. Samalla nuottikirjoitukselta on vaadittava, että se heijastaisi teoksen adekvaattista analyysiä. Haluaisin vetää myös johtopäätöksen, että yksiäänistä lineaarista lauluperinnettä kuvailtaessa voisi olla hyötyä myös niistä komposition ja nuottikirjoituksen periaatteista, jotka hallit- 
sivat musiikkiteoreettista ajattelua keskiajalla, kun muodostuvassa moniäänisessä musiikissa hallitsi vielä lineaarinen ajattelu.

\section{Rytmikuviot ja säe}

Edelleen täytyy tarkastella säkeen ja musiikillisen rytmin suhteita. Rytmi on tämä musiikillisen rakenteen aspekti, jossa säkeen ja samalla myös kielen prosodisen järjestelmän piirteet kietoutuvat musiikillisiin ilmiöihin. Kalevalamittaisen laulun rytmikuviot (eli rytmikaavat), joiden erittelyyn tässä tutkielmassa keskitymme, vastaavat normaalisäkeen tavumäärää ja yleistä rakennetta. Voidaan sanoa, että rytmikuvio liittää yhteen sanat ja sävelen.

Runonlaululle ovat tunnetusti tyypillisiä ryhmäsävelet, niin että periaatteessa samalla sävelellä voitaisiin esittää paljon erilaisia tekstejä. Muodollisesti voitaisiin kaikkia säveliä esittää kaikkien tekstien kanssa, mikä ei perinteen vuoksi tietysti voi tulla kyseeseen. Runonlaulun tärkeimpänä erityispiirteenä on säerakenne. Normaalisäkeessä on 8 tavua, jotka muodostavat tavallisimmin neljä runojalkaa, kaksi nelitavuista puolisäettä. Samalla juuri tämä kahdeksan tavun jakautuminen sanoihin ja painoryhmiin säkeen sisällä on kaikkein tavallisin vaihtelun kohde. Runojalassa on ensimmäinen tavu pitkä tai ainakin suhteellisen pitkä (poikkeuksena on ensimmäinen runojalka, joka voi olla vapaasti täytetty), toinen tavu on lyhyempi.

Sekä eestiläisessä että suomalaisessa runo-opissa runonlaulun yhteydessä on usein käytetty trokee-käsitettä, samalla se on myös tuomittu. Itse en haluaisi käyttää Länsi-Euroopassa uudella ajalla vahvistuneita klassisten runojalkojen nimityksiä sen takia, että tämä yhdenvertaistaa runojalan; nousu $=$ pitkä elementti, tavu $=$ painollinen elementti. Itämerensuomalaisissa kielissä painollinen elementti ei ole automaattisesti myös pitkä elementti. Tämä on runolaulun säkeen toimivuuden kannalta hyvin oleellista. Esimerkki: Normaalisäe on "Kas see kiike kannab meida" ( $\left.0^{-} \cup / 0^{\circ} \cup \cup / /^{\circ}-\cup / 0^{\circ} \cup /\right)$ "see" on pitkä tavu, mutta lauseessa suhteellisen painottomana se voi tarpeen vaatiessa esiintyä myös runojalan laskussa). Samasta laulusta säe "Kui ei kanna siis kadugu" $\left(\circ-\cup / 0^{-} \cup / / 0 \perp{ }^{\circ} /-\cup /\right)$ on aivan "normin" mukainen variaatio, jossa korkoryhmiin jakautumisen muutos sallii sekä "sekatahdin" että skandeeraa laulamisen, mutta jättää säerakenteen tärkeimmän osatekijän, pitkän ja lyhyen tavun säännönmukaisen vaihtelun paikoilleen. 
Edellä kuvatun säkeen perusteella saattaa syntyä kuva, että runonlaulun ainoan mahdollisen musiikillisen rytmin kaavan tulisi olla pitkän ja lyhyen keston säännönmukainen vaihtelu tai äärimmäistapauksessa myös tasainen syllabinen musiikillinen rytmi. Näin ei kuitenkaan ole. Seuraavassa pyrin tekemään selväksi sen, että pidän säerytmiä ja musiikillista rytmiä tietyssä määrin autonomisina järjestelminä, jotka tietyllä tavalla vastavuoroisesti toisaalta aiheuttavat ja toisaalta rajoittavat toisiaan. Runonlauluperinteessä on joitakin varsin laajasti levinneitä rytmikuvioita, joissa runojalan nousua ja sääntönä pitkää tavua vastaa lyhyt

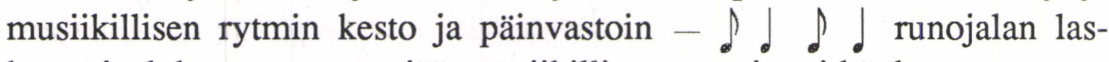
kuun ja lyhyeen tavuun jää musiikillisen rytmin pitkä kesto - mutta myös \」」 d ym. Tämä tuntuu olevan ristiriidassa perusperiaatteiden kanssa, joiden mukaan musiikkiteoriassa rytmiä on käsitelty. Keskiajalla pitkän ja lyhyen vaihtelussa syntyviä kuvioita, myöhemmin metriin perustuvia rytmejä on aina pyritty kuvailemaan runomittaopista lainattujen analogioiden avulla. Tietysti on muistettava, että klassisten kielten prosodia, keskiaikaisten kansankielisten säkeiden järjestelmät ja itämerensuomalainen runonlaulu ovat kaikki aivan eri asioita, joissa samanlaiset lait eivät voikaan olla voimassa. Mutta varmasti on myönnettävä, että musiikillinen rytmioppi on turhan paljon ollut sidoksissa klassisten, kvantiteettiin perustuvien runojalkojen teoriaan.

Esimerkiksi Barney Childs kirjoittaa englantilaisia runorytmejä ja nykymusiikin rytmiikkaa käsittelevässä artikkelissaan:

"The approppriation of the diacritics of poetic scansion, of the poetic feet themselves, for application in discussion of musical rhythm, has apparently been accepted by musical scolarship for many years. When Cooper and Meyer (1960), for example, provide their list of the five feet basic to musical rhythm (iamb, anapest, trochee, dactyl and amphibrach), these acceptably to establish patterns of strong and weak beats, they use the symbols for length $(-\cup)$ rather than stress $(/ \cup)$. This may have honorable historical precendence from a tradition of past German musical scolarship, but is still flatly inaccurate. The problem of agoging accent in music, of the relationship of duration to stress, is complex enough without the imprecesion and confusion that retention of this notation can produce" (Childs 1981:35). 
Lisättäköön tähän, että perinteisellä kulttuurialueellamme on saksalaisen musiikinteorian vaikutus ollut vielä paljon voimakkaampi kuin Amerikassa.

Ilmaisemme säerytmin ja musiikillisen rytmin suhteen näin: säerakenne rajoittaa kyllä musiikillisten rytmien valintaa, sanelee elementtien määrän ja niiden tietyn ryhmittelyn, mutta ei määrää yksiselitteisesti rytmiä. Kyseessä ei ole korkeamman ja matalamman tason suhde, vaan kahden järjestelmän (rytmisesti jäsennelty puhe ja musiikki) synteesi, jonka yhteydessä kummassakin saattaa toisen vaikutuksesta tapahtua pieniä muutoksia. Esimerkiksi kaksi musiikillisesti samanpituista kestoa itse asiassa poikkeavat toisistaan tuntuvasti, jos ne liittyvät eri pituisiin tavuihin ( $\square$ sanassa "kana" kuulostaa lähes $F$. mutta sanassa "kaela" suunnilleen $\sqrt{.7}$, vaikka laulaja haluaakin ne laulaa ja kuulija saattaa ne vastaanottaa musiikillisesti yhtä pitkinä nuotteina). Tietyissä rytmikuvioissa todellakin esiintyy lyhyiden tavujen venyttelyä, joka on itämerensuomalaisissa kielissä kaikkein vaarallisin kieliprosodian deformaatio. Prosodiset keinot kokonaisuudessaan takaavat kuitenkin aina sen, ettei sana venyttelystä huolimatta vääristy, mitä sittenkin tapahtuu varsin usein lauluja eestintäessä tai nykyaikaisia länsieurooppalaisia rytmejä eestinkieliseen musiikkiin siirrettäessä (esimerkiksi "me vap-rad mee-ri-poo-jad" - f . .

\section{Keskiaikainen modaalirytmiikka}

Millaisia modaalirytmiikan periaatteita voitaisiin sitten runonlaulun rytmikuvioita kuvailtaessa käyttää hyväksi? Keskiaikainen nuottikirjoitus kehitti pitkään ainoastaan sävelkorkeuksien merkintäjärjestelmää. Rytmi johtui tekstistä, ja aivan alussa kirjoitettiin melodian kulkua osoittavia merkkejä - neumeja - tekstin yläpuolelle. Musiikki perustui suulliseen traditioon, muotoutuvalla nuottikirjoituksella ei ollut monia niistä tehtävistä, joita myöhemmin alettiin pitää itsestäänselvinä. Aivan luonnollisesti nuotinta kehittyi hengellisen musiikin tarpeiden mukaan. Säännönmukaista rytmiikkaa musiikissa on yhdistetty runomuotoiseen tekstinlaulamiseen ja tanssimusiikkiin. Jo kaukaisessa menneisyydessä hymnit olivat runomuotoisia. Suunnilleen vuosituhansien vaihtuessa roomalaisen kirkon ohjelmistoon tuli runsaasti uusia runomuotoisia lisäyksiä - trooppeja, sekvenssejä yms.

Yksiäänisessä musiikissa ei itse asiassa ole välttämätöntä tarvetta rytmin merkitsemiseksi, tarve syntyy polyfonian kehittymisen myötä. 
Näin ollen ollaan sitä mieltä, että modaalirytmiikan perustana olevat modus eli rytmikuviot olivat todellisuudessa käytössä jo vuosisatojen ajan. Tämä koskee lähinnä kolmea ensimmäistä modusta, jotka liittyvät trokeeseen, jambiin ja daktyyliin. Kestot alkavat ilmestyä nuottikirjoitukseen 1100-luvun jälkipuoliskolla. 1300-luvun alkuun mennessä tai viimeistään 1300-luvun alussa muotoutuu jo rytmisesti tarkka mensuraalinotaatio, joka periaatteessa tekee mahdolliseksi merkitä nuottikirjoitukseen kaikenlaisia rytmejä kuinka monelle äänelle tahansa.

Modaalirytmiikkaa on rytmin merkintäjärjestelmän muotoutumisvaihe. Periaatteiltaan se vastaa vielä sellaista rytmistä ajattelua, joka ei kirjoittamista kaipaisi. Mutta kahden tai kolmen eri rytmistä kulkua omaavan äänen koordinointi osoittautuisi ilman rytmikuvioiden valmista järjestelmää mahdottomaksi. Varhaisemmista maallisen musiikin rytmeistä on tehty olettamuksia myöhempien nuottikirjoitusten perusteella, joihin on jo kuulunut rytmi. Perinteen jatkuvuuden ansiosta nämä ovat oikeimpia trubaduurilaulun kohdalla. 1100-1200-luvuilla oli musiikkiteoreettisen ajattelun johtavana maana Ranska, erityisen merkittävästi vaikuttivat Pariisin Jumalanäidin kirkon muusikot. Näin ollen myös modaalirytmiikan takaa paljastuu ennen kaikkea vanhoja, ranskankielisiä ja Ranskassa harrastettua latinankielisiä runoja laulettaessa käytetyt tavalliset rytmit. (Paljon on väitelty siitä, voidaanko modaalirytmiikkaa soveltaa saksalaisen keskiaikaisen laulukulttuurin yhteydessä vai ei.)

On varsin todennäköistä, että yksiäänisessä musiikissa käytettiin todellisuudessa paljon enemmän rytmikuvioita kuin niitä myöhemmin on pystytty rekonstruoimaan. Keskiaikaisen maallisen laulun rytmiikkaa sijoittuu rytmikuvioiden täsmällisyydeltä polyfonisen musiikin (modaalirytmiikka, myöhemmin mensuraalirytmiikka) pidättyvyyden ja vapaarytmisten resitoivien ja melismaattisten tyylien (myös varhainen polyfonia) välimaastoon. Johannes de Grocheo (n.1300) on huomauttanut, että musiikki, joka ei ole tarkasti mitattavissa (non praecise mensurata) ei ole vielä musiikkia (musica immensurabilis) (sit. Westrup 1954:226).

\section{Nuottikestojen ilmestyminen nuottikirjoitukseen}

Tutkielman aiheen kannalta on tärkeää seurata nimenomaan kestojen ilmestymistä nuottikirjoitukseen. 1100-luvun lopussa discantuksissa tehdään ero pitkän keston, longan (L) ja lyhyen keston, breviksen (B) välillä. Pitkän ja lyhyen keston suhteet eivät olleet ilmeisesti täysin selviä, sillä longa saattoi täyttää koko aikayksikön, tempuksen, mutta 
saattoi mahtua siihen myös yhdessä breviksen kanssa. Huomaamme, että kestot tulivat nuottikirjoitukseen juuri sillä tavalla kuin väitämme niiden kansanmusiikissamme olevan - kahtena vastakkaisena elementtinä, joiden tarkkoja kvantiteettisuhteita tärkeämpää on, että ne selvästi eroaisivat toisistaan. 1200-luvulla nuottikirjoitus muuttui rytmiikan osalta paljon joustavammaksi (ks. Aubry 1908: 115-142 ja Apel 1960). Breviksestä tuli itsenäinen yksikkö; longan ja breviksen eri yhdistelmistä muodostuivat modukset. 1260-luvulta peräisin oleva Franco Kölniläisen traktaatti "Ars cantus mennsurabilis" sisältää yksikön verran lyhyemmän keston, semibreviksen Teoksessa esitetään myös kestojen tarkat matemaattiset suhteet: longa $=$ brevis + brevis altera $=3$ brevista $=$ semibrevista.

Nyt ei "lyhyempi pitkä" ole enää pitkä, vaan pidennetty lyhyt - brevis altera. Voidaan pohtia, missä määrin nämä suhteet olivat matemaattisia (konseptuaalisia) ja missä määrin mekaanisia (todellakin sellaisissa suhteissa toteutettuja). Sallittakoon sivuhuomautus - juuri 1200-luvun lopussa tulivat käyttöön mekaaniset kellot. 1200-luvun musiikin rakenne ei itse asiassa vielä vaadi tarkkuutta nopeammissa liikkeissä, ja näin ollen riittää tempus, joka 1200-luvun alussa vastaa longaa, mutta vuosisadan lopussa aikaa mitataan breviksella (Franco Kölniläinen kuvailee tempusta minimaalisena kestona, jonka aikana pystyy kuulemaan täyden soinnin, minimum in plenitudine vocis). 1200-luvun jälkipuoliskolla torjuttiin moniäänisestä musiikista lähes tyystin mahdollisuus, että pienempi kesto voisi jakautua kahteen tasavertaiseen lyhyempään. 1300luvun alussa tämä palaa uudelleen kuvaan imperfektisen jaottelun muodossa (täydellinen ja epätäydellinen modus, tempus ym).

Täten olemme tavoittaneet myös kansanmusiikkimme teoreettiseen kuvaamiseen tarvittavat kestoyksiköt - kaksi peruselementtiä, pitkän ja lyhyen; pitkän voivat korvata sekä kaksi että kolme lyhyttä, yhtä hyvin myös pitkän-lyhyen tai lyhyen-pitkän yhdistelmä; lyhyitä nuotteja voi edelleenkin koristella korvattaessa ne vielä lyhyemmillä, mutta tällä tasolla ovat kestojen suhteet paljon epäselvempiä: tempus on yksi runojalka eli yksi pitkä kesto tai pitkän-lyhyen yhdistelmä. Mekaanisista kestoista ei tietenkään tällaista riviä voitaisi laatia: $\mathrm{L}->\mathrm{BB}->\mathrm{BBB}->$ LB $->$ BL. 


\section{Säettä vastaavan rytmikuvion muodostuminen}

Edelleen meitä kiinnostavat tuon ajan elementaaristen rytmikuvioiden, modusten, käyttämistavat. 1200-luvun puoliväliin mennessä muotoutuneessa rytmijärjestelmässä käytettiin kuutta modusta, joiden tärkeimmät rytmikuviot olisivat seuraavia. 1. modus - LB, 2. modus - BL, 3. modus LBB (kolmijakoisessa rytmissä siis LBBa - jälkimmäinen brevis on brevis altera), 4. modus - BBL (vastaavasti $\mathrm{BBaL}$ ), 5. modus - LL (tätä ainoastaan pitkissä kestoissa liikkuvaa rytmiä käytettiin pääasiassa tenorissa), ja 6. modus - BBB (nopeinta liikettä mahdollistava rytmi, esiintyi enimmäkseen triplumissa). Moduksen rytmikuvio, kaava toistuu tavusta toiseen tietyn määrän kertoja, näin muodostuu lause tai periodi, jota sanotaan ordoksi, tarkemmin primus ordo, secundus ordo jne. riippuen siitä, montako elementaarisen rytmikuvion toistoa ordoon sisältyy. Ordo olisi siis suurin rytmin yksikkö ja pienin muotoyksikkö olosuhteissa samalla myös ainoa musiikillisen muodon jäsentely-yksikkö. Ensimmäisessä moduksessa olisi esimerkiksi primus ordo - - $\downarrow_{d} \downarrow$ ฯ ;

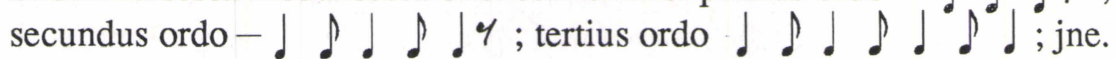

Aubry puhuu vielä musiikillisen rakenteen jäsentelyn välitasosta, jota hän sanoo distinctioksi:

"Aussi bien, suivant en ordre le complexité croissante, nous étudierons successivement: - la formula modale, - la distinction mélodique, membre de phrase musicale correspondant á un vers du texte, - la phrase mélodique, ou ordo, succession de formules modales comprises entre deux silences. L'ordo peut n'être composé que d'une seule distinction, mais il peut ausi en admettre plusieurs. La formule modale de la musique mesurée tend à la synthése dans la distinction et celle-ci va se fondre dans le groupemernt supérieur de la phrase musicale." (Aubry 1908:120).

Muista käsittelyistä en ole löytänyt tällaista kolmitasoista analyysia, ja jopa Aubryn analyyseissa distinctio käsite on usein vain rakenneyksikön synonyymi.

Mutta koska meitä eivät kiinnosta senaikaisen musiikin analyysi vaan rytmijärjestelmän periaatteet, niin tämän välitason mahdollisuudet kannattaa panna muistiin. Aubryn mukaan keskiaikaisen rytmiteorian kulmakivenä on säkeen yhteensovittaminen melodiaan, l'assimilation $d u$ vers ála distinction mélodique, eli kuten Guido Aretinus "Micro- 
loguksessa" ilmaisee (n. 1040): "Non autem parvasimilitudo est metris et cantibus cum et neume loco sint pedum et distimctiones loco versuum." (Aubry 1908:119).

Jos nyt johdetaan keskiaikaiset rakenteen jäsentelyn käsitteet vastaavuuteen runolaulussa käytettävien käsitteiden kanssa, saamme seuraavat tasot (korkeampi rakenneyksikkö voi sisältää luonnollisesti myös ainoastaan yhden matalamman rakenneyksikön; rakenteen yksittäinen elementti saattaa myös olla konkreettinen elementti, joka ei enää jakaudu vielä pienempiin koristeluelementteihin).

\section{Esimerkki 1.}

\begin{tabular}{|ll|ll|}
\hline \multicolumn{2}{|c|}{ Keskiaikaiset yksiköt } & \multicolumn{2}{c|}{ Runonlaulun rakenneyksiköt } \\
\hline sävelmä & stroofi & sävelmä & säepari tai toisto \\
\hline $\begin{array}{l}\text { ordo } \\
\text { (fraasi, säe) }\end{array}$ & säe, säepari & säe & säe \\
\hline $\begin{array}{l}\text { distinctio } \\
\text { (motiivi, } \\
\text { sävelaihe) }\end{array}$ & säe, säkeenosa & puolisäe & puolisäe \\
\hline $\begin{array}{l}\text { modus } \\
\text { (moduksen kaava) }\end{array}$ & runojalka & - & runojalka \\
\hline $\begin{array}{l}\text { elementti } \\
\text { (L tai B) }\end{array}$ & elementti, tavu & $\begin{array}{l}\text { elementti, } \\
\text { rytmikaavan } \\
\text { tavunuotti }\end{array}$ & $\begin{array}{l}\text { elementti, } \\
\text { normaalisäkeen } \\
\text { tavu }\end{array}$ \\
\hline $\begin{array}{l}\text { todellinen sävel, } \\
\text { melisma, } \\
\text { korusävel }\end{array}$ & $\begin{array}{l}\text { todellinen tavu, } \\
\text { lisäystavu } \\
\text { säkeessä }\end{array}$ & $\begin{array}{l}\text { todellinen sävel, } \\
\text { melisma, } \\
\text { korusävel }\end{array}$ & $\begin{array}{l}\text { todellinen tavu, } \\
\text { lisäystavu } \\
\text { säkeessä, äänet } \\
\text { melismoissa }\end{array}$ \\
\hline
\end{tabular}

Olen ajatellut, että distinctionin tason voisi myös jättää pois ja johtaa runonlaulun puolisäkeen (neljä elementtiä) vastaavuuteen moduksen kaavan kanssa. Musiikin kannalta tämä olisi ehkä parasta, useimmissa lauluissa olisi vaikeaa jakaa edelleen. Tekstin kannasta taas on epäilemättä parasta jättää runojalka vastaavuuteen moduksen ja runojalan kanssa. 


\section{Rytmikuvion koristelu ja muutokset}

Meitä kiinnostavat myös keskiajalla käytetyt skemaattisen rytminkoristelun ja muuttamisen mahdollisuudet. Aubry käsittelee kolmea keinoa equipollentia eli yhdenvertaistaminen, dilatatio eli laajentaminen (tarkoittaa samaa asiaa kuin myöhempi augmentatio) sekä contractio eli tiivistäminen (myöhemmin diminutio). Yksinkertaisin ja levinnein on epäilemättä equipollentia, joka itse asiassa tarkoittaa musiikille ikiomaa melismaattista koristelua. Yhdenvertaistaminen tarkoittaa tässä sitä, että elementin tilalle voi asettaa samankestoisen melisman. Tavallisesti melisma laulettiin yhdellä tavulla, mutta säkeeseen on mahdollista liittää myös ylimääräisiä tavuja. Joka tapauksessa equipollentia ei muuta elementtien määrää ordossa niin kuin väliin lisätty lyhyt ylimääräinen tavu ei muuta säerakennetta. On ymmärrettävää, että polyfonisen musiikin rytmijärjestelmän yhteydessä korostetaan koristelun kohdalla kestojen yhdenvertaisuutta - koko senaikainen rytmiin liittyvä teoreettinen ajattelu kehittyy tarpeesta koordinoida eri äänien kulkua ja kehittyy kohti yhä ankarampaa mittaa. Yksiäänisessä musiikissa ei kannata kestojen yhdenvertaisuuden vaatimusta yliarvioida - koristelussa pitkä kesto voi muuttua joskus lyhyemmäksi, joskus pitemmäksi, ilman että ajattelun perustana oleva rytmikuvio siitä muuttuisi:

Esimerkki 2.

a) Pitkät elementit eroavat toisistaan kestonsa perusteella. Tampere 1956-65, II:129 (A, No. 13), KM - Eü X 1833(3) ja 1886/7 (57).

iarju-jaani

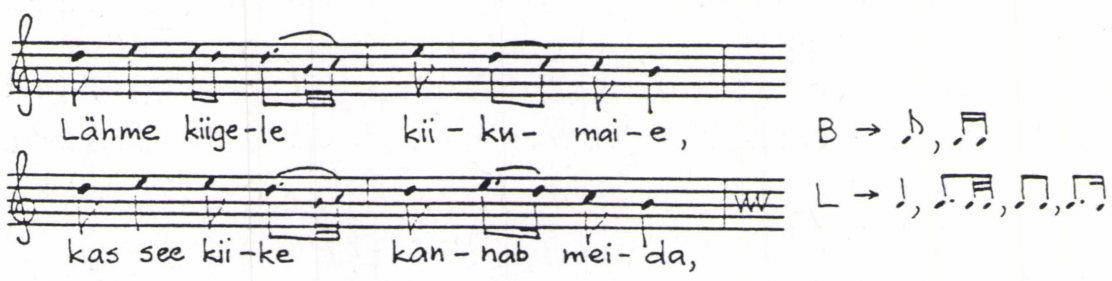

$B L B L B L B L$ 
b) Rytmiset horjahdukset ovat tavallisia laulun alussa. Myös modaalista häilyvyyttä esiintyy. Tampere 1956-65, II:132 (A, No. 16), KM - EüX 1841(30) ja 1965(179).

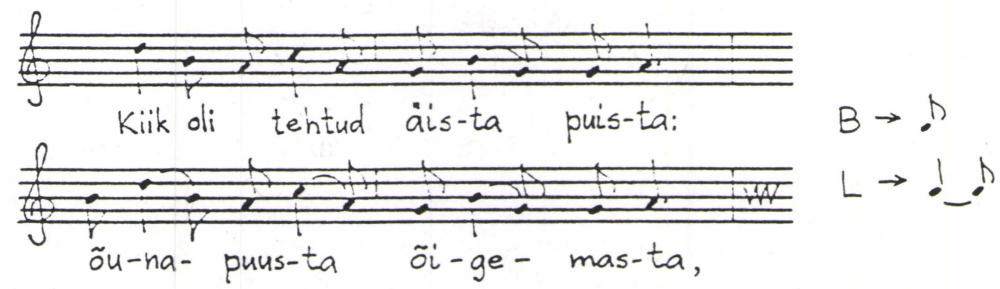

c) Tampere 1956-65, II:140 (A, No. 24), KM - EüS VII 2510/1(54) $1464 / 5(50)$.

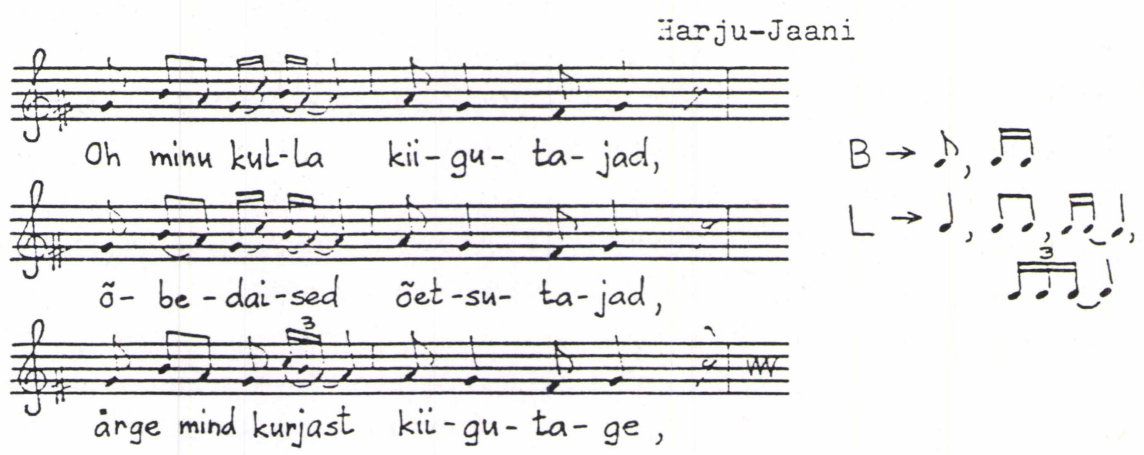

Muut rytmikuvion muuttamistavat ovat harvinaisempia, mutta silti musiikkiin kuuluvia ikiomia ilmiöitä. Dilatation eli laajentaminen tarkoittaa rytmikuvion jonkin osan tai koko periodin esittämistä pitempinä kestoina, niin että melodiayksikkö (distinction) venyy pitemmälle periodille (ordolle) kuin se olisi normaalia moduksen ja säkeen jälkeen tavumäärän puolesta. Esimerkiksi kolme tavua ensimmäisessä moduksessa vastaisivat normaalisti ordo primusta: d d 4 mutta jos jostakin syystä on tarve johtaa tämä vastaavuuteen saman moduksen ordo secunduksen kanssa, turvaudutaan dilatationiin: ل.」.」 4 . Contraction eli tihennys on juuri päinvastainen toiminta, ja sitä käytetään siinä tapauksessa, jos suuremman elementtimäärän omaava säe on johdettava yhteen pienemmän ordon kanssa. Esimerkiksi seitsemän tavua kolman-

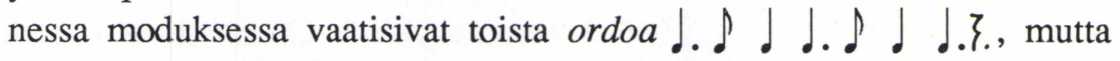
jos tämä osa on johdettava vastaavuuteen ordo primuksen periodin kans-

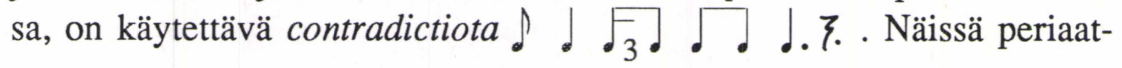


teissa on selvästi havaittavissa pyrkimys saattaa sopusointuun vertikaalissa (ajassa) eri äänien lineaarisia rakenteita. Miksi saattaisimme tarvita näitä teorioita yksiäänisen kansanlaulumme yhteydessä?

\section{Tempus}

Vaikka laulamisen aikamitta/tempo on runonlauluperinteessä selvästi yksilökohtainen emmekä valitse nuottikirjoitusta varten pitempiä muotoja, jos yksi laulaja laulaa muita selvästi hitaammin, perinteessä on ilmiselvästi olemassa keskimääräinen tempus, aikamitta, joka määräytyy puhenopeuden normaalipuitteiden mukaan. Laulaja, joka esittää uudempia lauluja hyvin erilaisissa tempoissa laulujen musiikillisia kuvioita ja sisältöä vastaavasti, esittää runonlauluja kuitenkin suurin piirtein samassa tempossa. Olen kirjoittanut nuotteihin muutaman laulajan äänitteitä, jotka on tehty noin viidentoista vuoden aikana - tempojen vaihtelevaisuus niissä on lähes olematonta ja sattumanvaraista. Mutta yhden laulajan keskimääräisenä tempona voi kyllä olla noin $\mathrm{MM}=60$ 70 , toisella taas $\mathrm{MM}=80$ paikkeilla jne. Tempuksena, aikamittana voisimme runonlauluissa pitää yhden runojalan tavuparia, musiikillisessa rytmissä tätä kaavaa vastaa neljännesnuotti, nykyisessä rytmisessä ajattelussamme keskimääräinen, yhtä iskua vastaava kesto. Kun musiikkihistorioitsijat tarjoavat tempuksen keskiaikaiseksi pituudeksi noin MM $=80$, niin tämä soveltuu mainiosti myös runonlauluun. Eestin runolaulun tempo vaihtelee rajoissa $\mathrm{MM}=60-100$, laulut menevät harvoin yli näiden rajojen, ja silloin huomaamme erittäin nopeata liikettä/kulkua (esimerkiksi Mustjalan häälaulussa)

1200-luvun alussa tempuksena oli longa, myöhemmin tempus orientoitui brevikseen, sen jälkeen semibrevikseen, pysytellen kuitenkin käytettävien kestojen skaalan/asteikon keskellä. Tästäkin aspektista voisimme verrata runonlauluja varhaiskeskiaikaisen musiikin kanssa, Tempus $=$ long $a=\mathrm{MM}=$ noin 80 . Tämä keskimääräinen tempo antaa aihetta puhua monien laulujen yhteydessä nopean (tiivistetyn) ja normaalin tai hitaan (laajennetun) ja normaalin rinnastuksesta myös yksiäänisissä runolauluissa. Meillä on myös yksi varsin laajalti levinnyt rytmikuvio, jossa runolaulun ensimmäinen runojalka on selvästi tiivistetty kaksi rakenteen kannalta tärkeää elementtiä yhden lyhyen elementin kestoon. Näin ollen tiivistämisen ja laajentamisen käsitteitä usein kuitenkin tarvitaan runonlaulua kuvatessa. 
Lähteet

Apel, Willi

1960 Die Notation der polyphonen Musik 900-1600. Leibzig 1970.

Aubry, Pierre

1908 Cent motets du IIIe siecle. III Etudes et commentaires. Paris.

Childs, Barney

1981 "Poetic and musical rhythm: one more time." Music

Theory. Special Topics. Ed. R. Brown. New York. pp. 33-57.

Lippus, Urve

1977 "The manifestation of some phonetic correlates of stress in the Estonian folk song." Estonian Papers in Phonetics. Tallinn. pp. 39-50.

1984 Estonskij runitseskij napev i metodika evo issledovanija. Dissertatsija na soisk. uts. st. kand. isk. Moskva.

Ross, Jaan

1988 "A Study of timing in Estonian runic song." (In print.) Sachs, Curt

1953 Rhythm and Tempo. New York.

Tampere, Herbert

1956-65 Eesti rahvalaule viisidega I-V. Tallinn.

1977 "Moned motted liivi rahvalaulust." Soome-ugri rahvaste muusikapärandist. Toim. Rüütel, I. Tallinn. lk.135-144.

Westrup, J. A.

1954 "Medieval song. Early medieval music up to 1300." The new oxford history of music, Vol. II. London. pp. 220269. 